Japan Social Innovation Journal, Vol. 6, No. 1, 2016

\title{
Human Security, Social Competence and Natural Disasters in Japan and New Zealand: A Case study of Filipino migrants
}

\author{
Maria Makabenta Ikeda and Arlene Garces-Ozanne
}

\begin{abstract}
This study applies a human security perspective in analyzing the consequences of the 2010/11 Canterbury (New Zealand) earthquakes and the 2011 Great East Japan earthquake and tsunami. It explores different factors that shape the vulnerability and resilience of individuals to natural hazards. We hypothesize that individuals differ in their vulnerability to- and capacity to recover from- disasters resulting from their demographic, social and economic characteristics. We take a closer look at how these disasters have affected the lives of a group of Filipino migrants and how they are able to cope with and recover from these calamitous experiences. Our analysis indicates that during natural disasters social competence (awareness, attitude, knowledge, communication skills) and social networks are very important mechanisms for coping and building resilience.
\end{abstract}

KEYWORDS: Human Security, Natural Disasters, Migrants, Filipino Community "bayanihan" Spirit, Vulnerability, Resilience, Japan, New Zealand

JEL CLASSIFICATION: A13, O53, O57, Q54

\section{INTRODUCTION}

This study puts together an analysis of two topics that have caught and continue to hold the attention of the whole world: disasters and migrants. Since 2000, the world has been witness to more than 6,240 natural hazards on an international scale. These include 421 earthquakes, 1,493 storms and 2,452 floods that resulted in over a million people dead, four million injured and over 34 million left homeless (Guha-Sapir et al. 2015). The catastrophic consequences of these hazards, in general, cannot be denied; but the devastation caused to the lives of individuals is not the same for everyone. This study provides an analysis of the social and economic vulnerability as well as the factors related to social competence that helps individuals and the communities they belong to become more resilient during natural disasters. Our study provides preliminary empirical evidence on the importance of social competence of migrants based on survey findings. It draws evidence from the unique experiences of Filipinos living in Christchurch and in the Tohoku and Kanto regions and affected by two disasters that have drawn much international attention in the last few years: the Great East Japan and Christchurch earthquakes. The economic and geographic locales of these disasters are quite diverse and this diversity provides a valuable framework to examine the social and economic vulnerabilities and resilience of migrants in different circumstances.

Previous empirical literature on natural disasters, vulnerability and resilience has typically focused on the national level (see for example Adger, 1999, Brooks et al. 2005, Cutter and Finch, 2007, Cordina, 2004, Guillamont, 2009, Naude et al., 2009) and sub-national levels (see for example Adams et al. 1998, and Rayhan, 2008). Our study is important and different in that we apply a human security

Maria Makabenta Ikeda is Associate Professor at the School of Economics of the University of Hyogo in Kobe. Arlene Garces-Ozanne is Lecturer at the University of Otago Department of Economics and a grantee of the Hyogo Overseas Research Network (HORN) Research Fellowship Program for 2015. 
perspective on a micro (individual) level in our analysis. Futamura et al. (2011) points out that taking a human security perspective directs attention to the needs of the most vulnerable population (women, children, and the elderly), and at the same time, emphasizes empowerment and inclusion strategies, enabling individuals and/or communities to better cope with and recover from natural disasters. Our study examines human security and natural disasters from the perspective of one such population: migrants.

Table 1: Background information on the Great East Japan Earthquake and the Canterbury/Christchurch Earthquakes

\begin{tabular}{|c|c|c|}
\hline & $\begin{array}{c}\text { Canterbury/Christchurch } \\
\text { Earthquakes }\end{array}$ & Great East Japan Earthquake \\
\hline Location & $\begin{array}{l}\text { Christchurch, Darfield } \\
\text { (Districts of Selwyn and } \\
\text { Waimakiriri) }\end{array}$ & $\begin{array}{c}\text { East Japan } \\
\text { (mainly Tohoku and Kanto regions) }\end{array}$ \\
\hline Date/Time & $\begin{array}{l}\text { 4 September 2010, 4:35 AM } \\
22 \text { February 2011, 12:51 PM }\end{array}$ & 11 March 2011, 2:46 PM \\
\hline $\begin{array}{l}\text { Magnitude } \\
\text { (Richter scale) }\end{array}$ & $\begin{array}{l}7.1 \\
6.3\end{array}$ & 9 \\
\hline $\begin{array}{l}\text { Size of quake- } \\
\text { affected area }\end{array}$ & 3,600 sq. km & 36,000 sq. km \\
\hline $\begin{array}{l}\text { Death toll (No. of } \\
\text { people missing) }\end{array}$ & 185 & $15,894^{1}$ \\
\hline $\begin{array}{l}\text { Foreign Nationals } \\
\text { among the } \\
\text { Fatalities }\end{array}$ & $\begin{array}{c}84 \\
\text { Japan (28), China (23), Philippines (11), } \\
\text { Thailand (6), Others (13) }\end{array}$ & $\begin{array}{c}41 \\
\text { China (16), Korea (15),Philippines (4), } \\
\text { USA (1), Others (5) }\end{array}$ \\
\hline Estimated damages & $\begin{array}{l}\text { NZ\$20 to } 30 \text { billion } \\
\text { (US\$15 to } 25 \text { billion) }\end{array}$ & $\begin{array}{c}16 \text { to } 25 \text { trillion yen } \\
\text { (US\$185 to US\$308 billion) }\end{array}$ \\
\hline
\end{tabular}

Sources: Parker, M. and Steenkamp, D. (2012). The economic impact of the Canterbury earthquakes, Reserve Bank of New Zealand: Bulletin, Vol.75, No. 3, September 2012, p. 14.

Updated from Ikeda, M., Matsumaru, M. (2012). Leadership and Social Innovation initiatives at the Grassroots during Crises, Japan Social Innovation Journal, Vol.2, No.1, p. 79, 2012.

Ministry of Health, Labour and Welfare (2012). Figures as of September 6, 2012.

National Police Agency of Japan. (2015). Damage Situation and Police Countermeasures associated with 2011

Tohoku district - off the Pacific Ocean Earthquake. Figures as of Jan 8, 2016.

New Zealand Police website. List of Deceased. Figures as of February 9, 2012.

Located in the Pacific Ring of Fire - an area in the basin of the Pacific Ocean, both New Zealand and Japan are frequently subject to earthquakes and volcanic eruptions. However, none has wreaked as much havoc to these two countries in recent decades as the series of earthquakes leading to the February $22^{\text {nd }}$ earthquake in Christchurch ${ }^{2}$ and March $11^{\text {th }}$ in East Japan. Both earthquakes caused much damage to public and private properties, critical infrastructure such as hospitals, schools, roads, rail tracks and caused massive disruption in lifelines such as gas, power and water supply. When disasters strike, everyone living in these areas is affected. Among the 185 people killed in Christchurch, 84 people or $45.4 \%$ were from 20 different countries most of whom came from Japan, China and the Philippines. In the 2011 Japan earthquake, according to government statistics, 41 people or $0.26 \%$ of those confirmed dead were from China, South and North Korea, the Philippines, the United States, Canada, and Pakistan.

The main objective of this study is to provide a framework for analysing the human security and resilience of migrants during and after natural disasters. Migrants refer to those who have lived

1 According to the latest statistics of the National Police Agency of Japan, this figure does not include the 2,563 unaccounted for or missing people as of January 8, 2016.

2 New Zealand's GNS Science has stated that the February 22nd earthquake is part of a series of aftershocks from the September 4th earthquake. However, others (e.g. Geoscience Australia) contend that this was not an aftershock, but a separate earthquake based on the fault line where it occurred. 
outside their places of birth for more than one year to seek better quality of life in another country. For the purposes of this study, we focus on Filipino migrants who are neither refugees nor asylum seekers. These migrants are in the same boat as the locals and everyone else when disaster strikes a community. They have the same needs like food and water, medical care, shelter and security. Like everyone else, all they want is to go back to their homes, jobs and to regain normalcy in their lives. However, migrants have unique issues during times of crisis.

We analyze migrant human security issues because migrants have been considered in some studies (see for example Naik 2007) to be more socially and economically vulnerable than locals during natural disasters for many reasons, and as such may be less socially competent to deal with adversities than locals. For example, migrants may not be as familiar with the locale, the different agencies or organizations that they can go to for help during disasters. If migrants were not very fluent with the local language or were illegal or irregular, this may make it more difficult for them to recover, express their needs, and interact with members of their community for support during chaotic and uncertain situations. They may also lack social networks and/or may not be as financially secure as locals, affecting how they cope with and recover from the disasters.

Specifically, this study explores the demographic characteristics of Filipino migrants in Canterbury and East Japan (Tohoku and Kanto) regions that determine their social or cultural competence level. We identify which characteristics contribute to vulnerability or could threaten security and transition to growth and recovery; and on the other hand, characteristics of resilience that enhance recovery notwithstanding difficult conditions during natural disasters. It also broadens the existing knowledge of factors and assesses current practices that promote disaster mitigation and recovery with a view to recommending more socially inclusive policies and strategies for improved disaster management.

\section{REVIEW OF LITERATURE}

Previous researches in general, implicitly assume that effects on individual members of society are the same for everyone. Furthermore, population growth and distribution, including density and urbanization have been found to increase vulnerability to disasters (see for instance Perrow, 2007). However, in this study, we contend that such an assumption is insufficient. We hypothesize that differences in individual characteristics, or group of individuals and their situation, substantially change the dynamics of analyzing the real extent of the impact of natural disasters, and consequently, the migrant's ability to cope with, and recover from the impact of a natural hazard. Analyzing the human security dimensions of the consequences of natural disasters is an important step in improving the way we prepare for and respond to natural disasters.

The literature on human security, in particular with respect to social and economic vulnerability during and after natural disasters is still evolving, with new definitions, causes and analytical methods being proposed (Gordon 2004, Cutter and Finch 2007, and Futamura et al. 2011). Human security is a complex concept popularized by the United Nations and typically associated with the vulnerability of populations to hazards of war, terrorism, ethnic violence, climate change, etc. (United Nations 2009). Futamura et al. (2011) argues the urgent need for considering human security issues in the face of natural disasters, in part because the occurrence of natural disasters is just as difficult to anticipate and fully prepare for, and its consequences just as devastating as wars, terrorism, etc. In fact, since the new millennium, much research on natural disasters has incorporated issues of vulnerability, albeit at the national level, including resilience.

de Ville de Goyet et al. (2006) analyzes disaster vulnerability as a result of physical, social, economic, and environmental factors that increase the predisposition of a community to the consequences of hazards. However, a strong coping capacity that combines all the strengths and resources available within a community can help mitigate the negative impacts and reduce a communities' vulnerability. This study provides a valuable insight regarding the importance of a more coordinated disaster preparedness, response and rehabilitation among national, local authorities and the population 
affected.

Duncan (2013) notes that foreign residents who do not understand, read or speak the local language can be very vulnerable; and for the host society under the pressure of extreme crises, these people are easily seen as a liability or additional problem to deal with. Citing news reports of Filipinos, Chinese and Pakistanis who decided to stay and help in disaster relief activities after the March 11 earthquake in East Japan, Duncan calls on policymakers not to concentrate on foreigners as liabilities but to secure roles for them as assets, particularly in disaster response and recovery. He points out that this will only work under a platform of social inclusion that would entail discussion and collaboration with foreign residents as well as immigrant groups and NGOs in emergency planning. Duncan argues that as long as foreign residents are made aware of how they can help and that their efforts are welcomed by the host society, foreign residents can prove that through social integration they are given a chance to share common goals with their host society.

A social vulnerability index (SVI), based on socioeconomic and demographic factors that affect the resilience of communities is suggested by Flanagan et al. (2011). It is crucial to identify the most vulnerable people because their needs are not sufficiently considered in the planning of authorities, local response and relief organizations. The SVI is based on (1) Socioeconomic Status (income, poverty, employment, and education variables); (2) Household Composition/Disability (age, single parenting, and disability variables); (3) Minority Status/Language (comprising race, ethnicity, and English-language proficiency variables); and (4) Housing/Transportation (comprising housing structure, crowding, and vehicle access variables). Due to data and time limitations we do not compute for an index here, but our current study partially adopts Flanagan et al.'s (2011) concept of social vulnerability to identify the individual characteristics and behaviour that help one overcome one's own vulnerability especially in dire circumstances and harness certain skills that enhance social and cultural competence, a sense of community and resilience.

\section{FILIPINO MIGRANTS IN CHRISTCHURCHAND TOHOKU/KANTO}

In 2015, some 244 million people live outside the country of their birth. This means that international migrants roughly comprise $3.3 \%$ of the world's population. According to $\mathrm{Mr}$. Wu Hongbo, the United Nations Under-Secretary-General for Economic and Social Affairs "The rise in the number of international migrants reflects the increasing importance of international migration, which has become an integral part of our economies and societies. Well-managed migration brings important benefits to countries of origin and destination, as well as to migrants and their families."3

Filipino migrants ${ }^{4}$ currently make up one of the fastest growing ethnic groups, both in New Zealand and Japan. (See Tables 2 and 3) According to recent statistics released by the Japanese government, there are 217,585 Filipinos residing in Japan as of the end of December 2014. The Filipinos, with a 10.3 percentage share of total foreign nationals living in Japan, are the third largest ethnic group after the Chinese and Koreans.

Christchurch, which accounts for $8 \%$ of the total GDP, is the second most important city of New Zealand. Manufacturing, services as well as the education sectors are major employers. The presence of well-known universities attracts many young people to this city. The region of Tohoku, which consists of the six prefectures of Akita, Aomori, Fukushima, Iwate, Miyagi and Yamagata and account for approximately 4 to 6 percent of Japan's GDP. Major industries are the electronics (parts, devices, equipment and supplies), agriculture and fisheries, food, transportation equipment, chemical products, production machinery, fabricated metal products and electrical machinery equipment and supplies industries.

3 United Nations Sustainable Development blog. (2016). accessed 2016-1-27.

4 In New Zealand, data on the ethnic profile of migrants from the census may include New Zealand citizens who were born in the Philippines. On the other hand, the data from Japan's Immigration Bureau do not include Philippine-born residents holding Japanese citizenship. 
Japan Social Innovation Journal, Vol. 6, No. 1, 2016

Table 2: Number of foreign national residents in Japan (As of December 2014)

\begin{tabular}{|l|c|c|c|}
\hline Country of origin & $\begin{array}{c}\text { Number of foreign } \\
\text { national residents }\end{array}$ & $\begin{array}{c}\text { Percentage } \\
\text { share }\end{array}$ & $\begin{array}{c}\text { Growth } \\
2013-2014\end{array}$ \\
\hline Total & $\mathbf{2 , 1 2 1 , 8 3 1}$ & $100 \%$ & $2.68 \%$ \\
\hline China & 654,777 & $30.86 \%$ & $0.90 \%$ \\
\hline Korea & 501,230 & $23.62 \%$ & $-3.60 \%$ \\
\hline Philippines & 217,585 & $10.25 \%$ & $4.00 \%$ \\
\hline Brazil & 175,410 & $8.27 \%$ & $-3.30 \%$ \\
\hline Viet Nam & 99,865 & $4.71 \%$ & $38.20 \%$ \\
\hline U.S.A. & 51,256 & $2.42 \%$ & $2.60 \%$ \\
\hline Other & 421,708 & $19.87 \%$ & $9.57 \%$ \\
\hline
\end{tabular}

Source: Statistics Bureau, Ministry of Internal Affairs and Communications of Japan.

Table 3: Number of people in New Zealand who were born overseas (as of 2013)

\begin{tabular}{|l|r|}
\hline England & 215,589 \\
\hline China & 89,121 \\
\hline India & 67,176 \\
\hline Australia & 62,712 \\
\hline South Africa & 54,276 \\
\hline Fiji & 52,755 \\
\hline Samoa & 50,661 \\
\hline Philippines & 40,350 \\
\hline
\end{tabular}

Source: Statistics NZ Census 2013

Notes: Data refer to the birthplace of the usual resident population during the New Zealand census night 2013.

Table 4: Some Basic Demographic characteristics of Philippine-born residents in Christchurch

\begin{tabular}{|l|c|c|c|}
\hline & $\mathbf{2 0 0 1}$ & $\mathbf{2 0 0 6}$ & $\mathbf{2 0 1 3}$ \\
\hline Male & 186 & 336 & 1,596 \\
\hline Female & 450 & 669 & 1,809 \\
\hline Median age male & 19.6 & 22.5 & 27.9 \\
\hline Median age female & 34.9 & 35.9 & 33 \\
\hline
\end{tabular}

Source: Statistics NZ Census years 2001, 2006 and 2013

Table 5: Some Basic Demographic characteristics of Filipinos residing in Japan

\begin{tabular}{|l|c|c|c|}
\hline & $\mathbf{2 0 0 6}$ & $\mathbf{2 0 1 0}$ & $\mathbf{2 0 1 4}$ \\
\hline Male & 41,178 & 46,216 & 52,508 \\
\hline Female & 152,310 & 163,965 & 165,077 \\
\hline Total & 193,488 & 210,181 & 217,585 \\
\hline Median age male & 28.3 & 27.3 & 26.4 \\
\hline Median age female & 33.9 & 31.8 & 37.8 \\
\hline
\end{tabular}

Source: Ministry of Justice of Japan

Notes: Figures for 2006 and 2010 represent the number of persons registered in accordance with the Alien Registration Law and for 2014, the number of foreign national residents (includes medium-/long-term residents and special permanent residents) covered by Japan’s Immigration Control and Refugee Recognition Act. Due to the change in measurement and definition, data series after 2010 are not perfectly comparable. Figures shown are as of the end of December of each year. 
Japan Social Innovation Journal, Vol. 6, No. 1, 2016

Table 6: Total number of Filipinos residing in the Tohoku and Kanto regions of Japan

\begin{tabular}{|c|c|c|c|}
\hline & Total & Male & Female \\
\hline Japan & 217,585 & 52,508 & 165,077 \\
\hline Tohoku Region & 6,074 & 820 & 5,254 \\
\hline Aomori & 535 & 51 & 484 \\
\hline Iwate & 956 & 183 & 773 \\
\hline Miyagi & 1,102 & 179 & 923 \\
\hline Akita & 612 & 42 & 570 \\
\hline Yamagata & 675 & 46 & 629 \\
\hline Fukushima & 2,194 & 319 & 1,875 \\
\hline Kanto Region & 99,755 & 22,098 & 77,657 \\
\hline Ibaraki & 8,194 & 2,784 & 5,410 \\
\hline Tochigi & 3,872 & 934 & 2,938 \\
\hline Gunma & 6,070 & 1,311 & 4,759 \\
\hline Saitama & 17,147 & 4,005 & 13,142 \\
\hline Chiba & 16,375 & 3,562 & 12,813 \\
\hline Tokyo & 29,192 & 5,211 & 23,981 \\
\hline Kanagawa & 18,905 & 4,291 & 14,614 \\
\hline
\end{tabular}

Source: Statistics Bureau, Ministry of Internal Affairs and Communications of Japan.

Note: As of December 2014

The demographics of Filipino migrants in New Zealand and Japan are very similar. The median age (20s to 30s) of the Filipino migrants in both countries shown in Tables 4 and 5 imply that they comprise the working age population of their host countries. More Filipino women than men tend to migrate and settle in these two countries as shown in the data. In New Zealand, the Filipino population more than tripled from 11,091 people in 2001 to 40,350 in 2013. There are 6,074 Filipinos living in the Tohoku region of Japan and the majority or $86.5 \%$ are women, mostly spouses of Japanese (see Table 6). One of the authors has met some of them on field visits for interviews in Miyagi and they revealed that most of them came as young brides approximately twenty years ago. Most of them have gained permanent resident status while some are medium-/long-term residents. Table 7 briefly summarizes the visa or residence status of Filipinos in Japan as of the end of 2014 with a breakdown for the six prefectures of the Tohoku region as well.

In this study, we focus on analyzing the characteristics that affect the vulnerability and resilience of Filipino migrants who experienced the 2010 and 2011 earthquakes in Christchurch, New Zealand and Eastern Japan (Tohoku and Kanto regions) respectively and chose to stay after the disasters. In spite of losses both in properties and lives of family and friends, most of these Philippine-born residents decided to stay and help rebuild their communities. 
Japan Social Innovation Journal, Vol. 6, No. 1, 2016

Table 7: Visa status of Filipinos residing in Japan with Kanto and Tohoku breakdown

\begin{tabular}{|c|c|c|c|c|c|c|c|c|c|c|c|c|c|c|c|c|}
\hline Residence status/ & Japan & Kanto & Tokyo & Kanagawa & Saitama & Chiba & Ibaraki & Gunma & Tochigi & Tohoku & Fukushima & Miyagi & Iwate & Yamagat & Akita & Aomori \\
\hline Total No. of Filipinos & 217,585 & 99,755 & 29,192 & 18,905 & \begin{tabular}{|l|}
17,147 \\
\end{tabular} & 16,375 & 8,194 & $6,6,070$ & 3,872 & 6,074 & 2,194 & \begin{tabular}{|l|}
1,102 \\
\end{tabular} & 956 & 675 & 612 & 535 \\
\hline \begin{tabular}{|l|l} 
Permanent residents \\
\end{tabular} & 115,857 & 54,695 & 16,436 & 10,260 & 10,082 & 8,918 & 3,689 & 3,210 & 2,100 & 4,022 & 1,391 & 700 & 585 & 516 & 464 & 366 \\
\hline Long term residents & 43,997 & 19,335 & 4,763 & 3,384 & 3,251 & 3,380 & 2,308 & 1,328 & 921 & 553 & 283 & 91 & 59 & 35 & 48 & 37 \\
\hline \begin{tabular}{|l} 
Spouses or children of \\
Japanese nationals
\end{tabular} & 29,150 & 13,397 & 4,070 & 2,436 & 2,177 & 2,324 & 1,009 & 878 & 503 & 842 & 357 & 151 & 120 & 75 & 66 & 73 \\
\hline Technical intern training & 12,721 & 3,046 & 254 & 351 & 648 & 616 & 720 & 295 & 162 & 465 & 116 & 77 & 183 & 44 & 12 & 33 \\
\hline \begin{tabular}{|l|}
$\begin{array}{l}\text { Spouses or children of } \\
\text { permanent residents }\end{array}$ \\
\end{tabular} & 4,229 & 2,051 & 545 & 403 & 345 & 354 & 190 & 131 & 83 & 15 & 7 & 2 & 1 & & 2 & 3 \\
\hline \begin{tabular}{|l|} 
Dependents of \\
working visa holders
\end{tabular} & 2,332 & 1,553 & 564 & 449 & 184 & 199 & 44 & 87 & 26 & 24 & & 16 & & & 1 & 7 \\
\hline Engineers & 2,164 & 1,460 & 387 & 617 & 122 & 196 & 24 & 95 & 19 & 17 & 2 & 7 & 6 & - & - & 2 \\
\hline 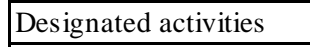 & 1,956 & 1,257 & 944 & 156 & 40 & 60 & 33 & 9 & 15 & 28 & 11 & 2 & - & - & 7 & 8 \\
\hline $\begin{array}{l}\text { Specialists in humanities } \\
\text { \& international service }\end{array}$ & 1,290 & 896 & 514 & 179 & 84 & 70 & 20 & 10 & 19 & 29 & 4 & 14 & & 2 & 7 & 2 \\
\hline Intracompany transfers & 1,132 & 827 & 154 & 452 & 83 & 93 & 30 & 9 & 6 & - & - & - & - & - & - & - \\
\hline College students & 1,013 & 575 & 349 & 72 & 38 & 73 & 31 & 5 & 7 & 27 & 4 & 18 & - & - & 4 & 1 \\
\hline $\begin{array}{l}\text { Musicians, sports, } \\
\text { entertainers etc. }\end{array}$ & 436 & 70 & 2 & 53 & - & 14 & -1 & 1 & - & 20 & 17 & 3 & & - & - & \\
\hline Skilled labourers & 376 & 158 & 55 & 13 & 26 & 9 & 55 & - & - & 5 & - & 5 & - & - & - & - \\
\hline Instructors & 332 & 177 & 50 & 38 & 34 & 29 & 13 & 7 & 6 & 9 & 2 & 4 & 2 & - & - & 1 \\
\hline \begin{tabular}{|l} 
Religious activities \\
\end{tabular} & 225 & 97 & 44 & 19 & 11 & 13 & 6 & 3 & 1 & 3 & - & 2 & - & - & 1 & \\
\hline Trainees & 123 & 49 & 14 & 8 & 11 & 8 & 4 & - & 4 & 6 & - & 4 & - & 2 & - & \\
\hline Professors & 92 & 25 & 13 & 2 & 1 & 4 & 4 & 1 & - & 6 & - & 6 & - & - & - & - \\
\hline $\begin{array}{l}\begin{array}{l}\text { Investors and business } \\
\text { managers }\end{array} \\
\end{array}$ & 52 & 38 & 18 & 6 & 4 & 5 & 4 & 1 & - & 1 & - & - & & 1 & & - \\
\hline Others & 108 & 49 & 16 & 7 & 6 & 10 & 10 & & - & 2 & - & - & - & & & 2 \\
\hline
\end{tabular}

Source: Statistics Bureau, Ministry of Internal Affairs and Communications of Japan.

Notes: As of December 2014. The category “Others” include Filipino residents who are categorized as exceptional permanent residents, researchers, those learning Japanese culture, those involved in medical services, legal and accounting services. 


\section{METHODS OF ANALYSIS}

\subsection{Data Collection}

Our analysis of human security and resilience at the individual level draws from the experience of Filipino migrants who live in Christchurch, New Zealand, and the Tohoku and Kanto regions in Eastern Japan. Information about their demographic characteristics and specific earthquake experiences were gathered through an online survey and personal interviews.

The surveys were not completely random sampled, but a form of respondent-driven sampling (RDS), a variation of snowball sampling. Pilot interviews were done in March 2015 in Miyagi and in September 2015 in Christchurch. Based on the responses of those initial interviewees, other survey respondents who meet the eligibility criteria (adult Filipino migrants who experienced the earthquakes were nominated and requested to complete the online surveys that ran from September 2015 to February 2016. This particular sampling method assumes that those best able to access members of target populations are their own peers, and is advantageous in that it allows the researchers (through the initial contacts) to locate people of a specific population (Filipinos affected by the earthquakes), and is also a simple, efficient and low-cost sampling method.

We sent our survey link to individuals living in the affected areas of Japan and New Zealand through friends and social networks like Facebook. Participation was voluntary. Sluggish feedback from the initial implementation of the Christchurch survey (40 questions) prompted us to trim down the survey. For the Tohoku/Kanto survey, there are 18 questions to enable respondents to complete the survey in 10 minutes or less. This paper utilizes only selected survey questions related to social competence skills (awareness, attitude, knowledge, communication capabilities) that are hypothesized to be linked to enhancing security, coping and resilience after disasters.

\subsection{Participants}

For the Christchurch survey, there were 24 respondents with an average age of 40 years. Females made up $83 \%$ and males $17 \%$ of the sample wherein more than half (67\%) are married, only $4 \%$ are separated or divorced while $21 \%$ has never been married. Similarly for the East Japan (Tohoku and Kanto) survey, there were 25 respondents with an average age of 39.76 years. The sample is $86 \%$ female and $14 \%$ male. In addition, $68 \%$ are married, $16 \%$ have divorced or separated from their partners and another $16 \%$ are still single. The majority of the respondents are currently living in Miyagi (44\%) while 32\% are in Kanto (all in Tokyo), 20\% are residents of Iwate and $4 \%$ are in Yamagata prefecture.

\subsection{Hypothesis}

We hypothesize that specific migrant characteristics that foster social competence or awareness not only affect how they cope with and recover from natural disasters but that these characteristics also influence their motivations for self-help and mutual cooperation. Aota (2012) explains how self-help and mutual cooperation or the so-called "new public commons" are crucial for human security through the implementation of post-quake relief, recovery and reconstruction activities by citing various examples in the Japanese experience. We argue in this study that the inclusion and integration of migrants are essential in designing disaster management programs for any community or region.

Our survey questions cover the socioeconomic variables such as age, income, employment and education as well as the language proficiency and some ethnicity variables as described in Flanagan (2011). In analyzing the results, we will link Flanagan's variables with the components of social 
Japan Social Innovation Journal, Vol. 6, No. 1, 2016

competence explained above. Recognizing that both verbal and nonverbal language is very important in not only conveying one's needs and ideas but also in interacting with people inside and outside one's own community and in the process gaining the trust of people.

Unlike previous studies, this study adds to the paucity of literature on the analysis of human security at the individual level and natural disasters, by examining how Filipino migrants in Christchurch and Tohoku/Kanto regions were affected by disasters: how they reacted, coped with and helped with recovery efforts and building resilience.

\section{SURVEY RESULTS: Awareness, attitudes, knowledge and communication skills of Filipino migrants}

In both samples, most of the Filipinos surveyed are long-term residents (Tables 2a-2b) where 83.4\% of the respondents have been living in either Tohoku or Kanto regions for more than 7 years and more than half of the sample size (54.2\%) have been staying in Japan for more than 10 years. As shown in Figure 1a, more than 80\% of the Filipinos surveyed in New Zealand either are permanent residents or have adopted NZ citizenship. But for those in Japan, notwithstanding their long-run stay, Figure $1 \mathrm{~b}$ shows that $46.2 \%$ of respondents are holders of a spouse or dependent visa and only $38.5 \%$ have been granted permanent residency or Japanese citizenship.

Figure 1a: Immigration status of respondents in Christchurch

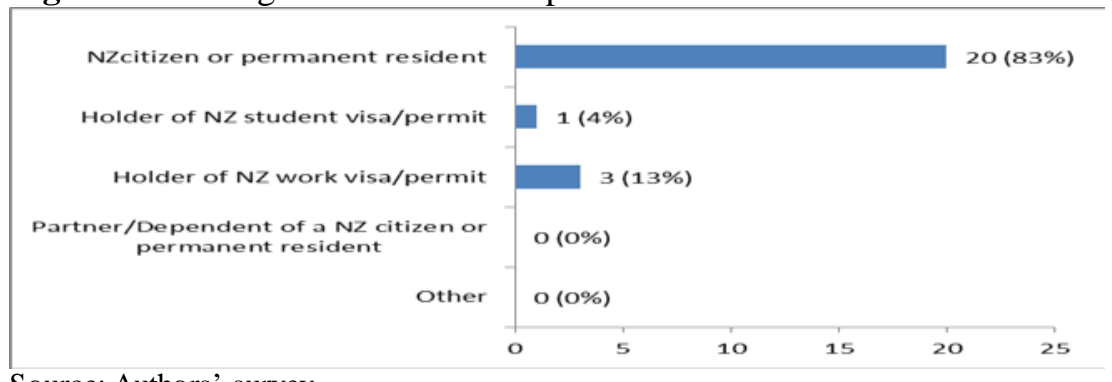

Source: Authors’ survey

Figure 1b: Immigration status of respondents in East Japan (Tohoku/Kanto)

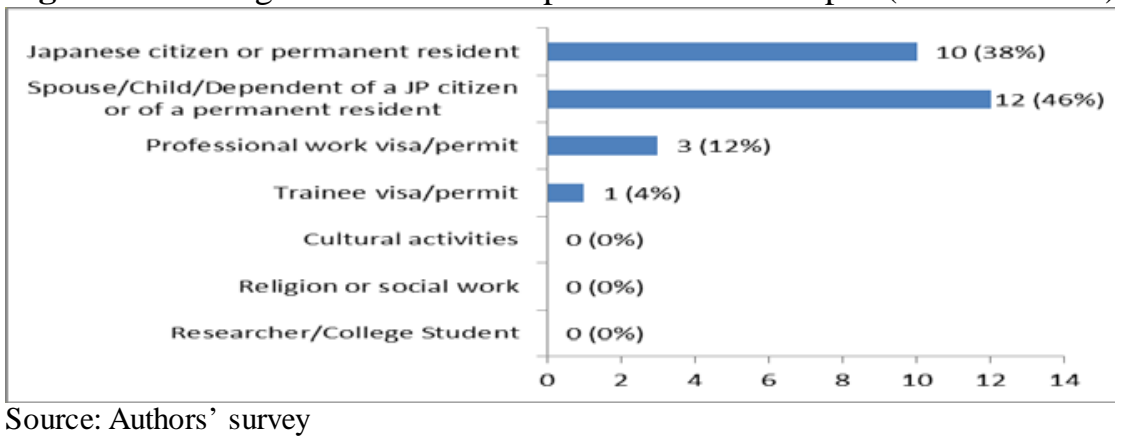

Figure 2a: Years Lived in Christchurch

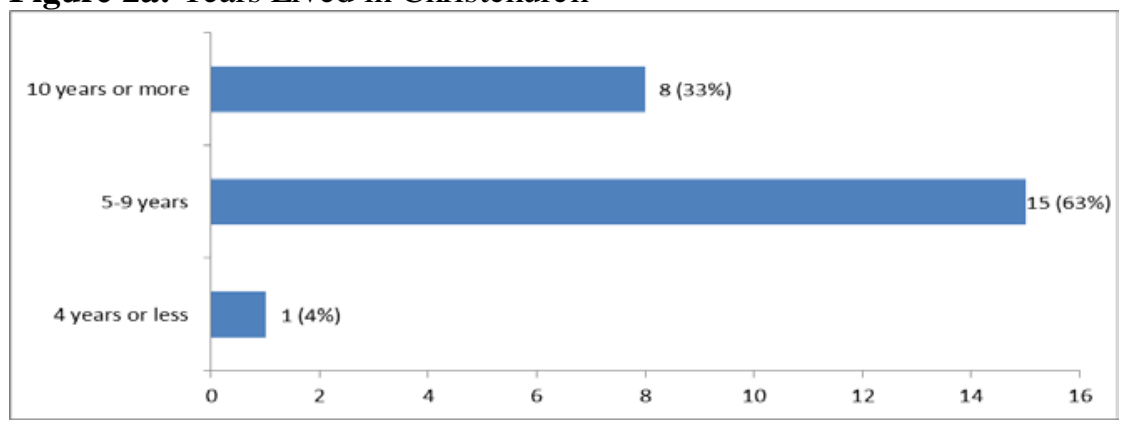


Japan Social Innovation Journal, Vol. 6, No. 1, 2016

Source: Authors’ survey

Figure 2b: Years Lived in East Japan (Tohoku/Kanto)

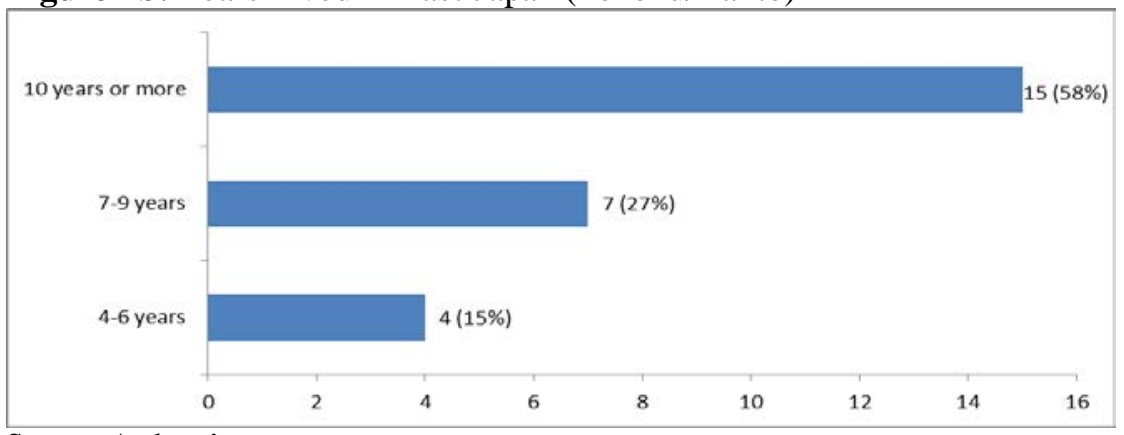

Source: Authors’ survey

Figure 3a. Educational Qualification of Christchurch respondents

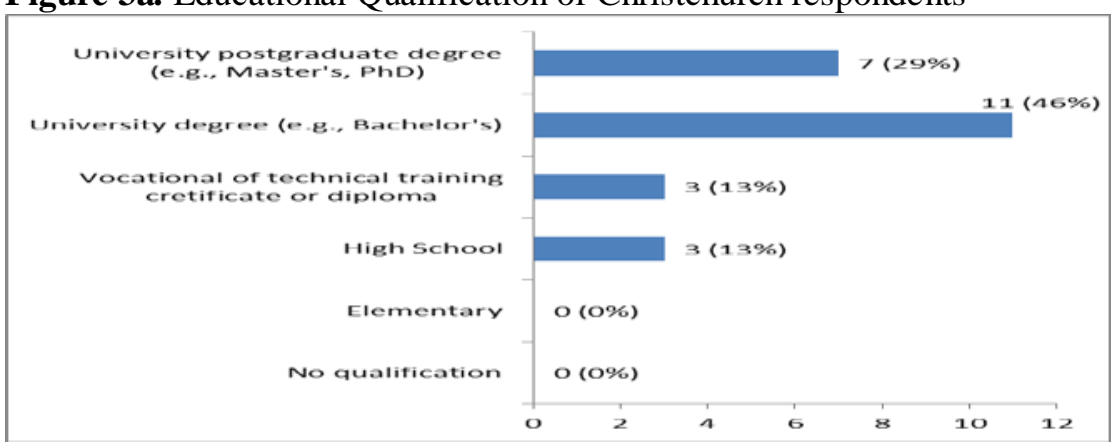

Source: Authors’ survey

Figure 3b. Educational Qualification of Tohoku/Kanto respondents

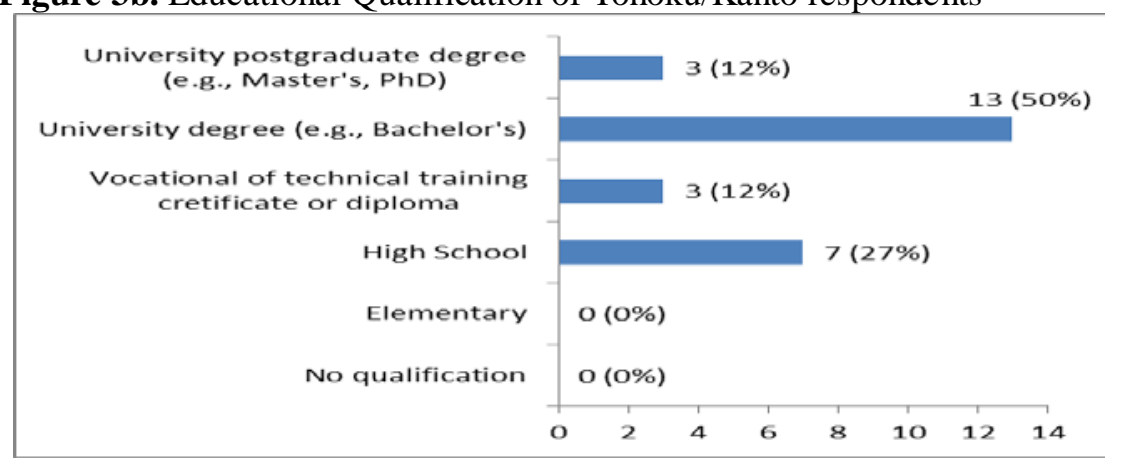

Source: Authors’ survey

For this run of the surveys, Figures 3a-b results show that half of the respondents in Japan have university degrees and around one-third of the sample is composed of high school graduates and/or have technical qualifications or vocational training. Likewise, most of Filipinos in Christchurch have a college degree, however, there are less high school graduates, and more people who have post-graduate degrees among the Filipinos who are currently staying in Christchurch. For Figures 4-6, the questions allowed for multiple answers. We asked these questions to gauge how Filipinos were able to cope under extreme traumatic situations they went through and how they utilize connections within their communities. Figures 4a-b show that more than half of the respondents in New Zealand and Japan participate in community meetings. Noteworthy is that, more Filipinos in Japan took or are taking the extra effort to join cross-cultural gatherings with their hosts, the Japanese. 
Institute for Policy Analysis and Social Innovation, University of Hyogo Published online: March 31, 2016

Japan Social Innovation Journal, Vol. 6, No. 1, 2016

Figure 4a. Awareness on social, community involvement in Christchurch

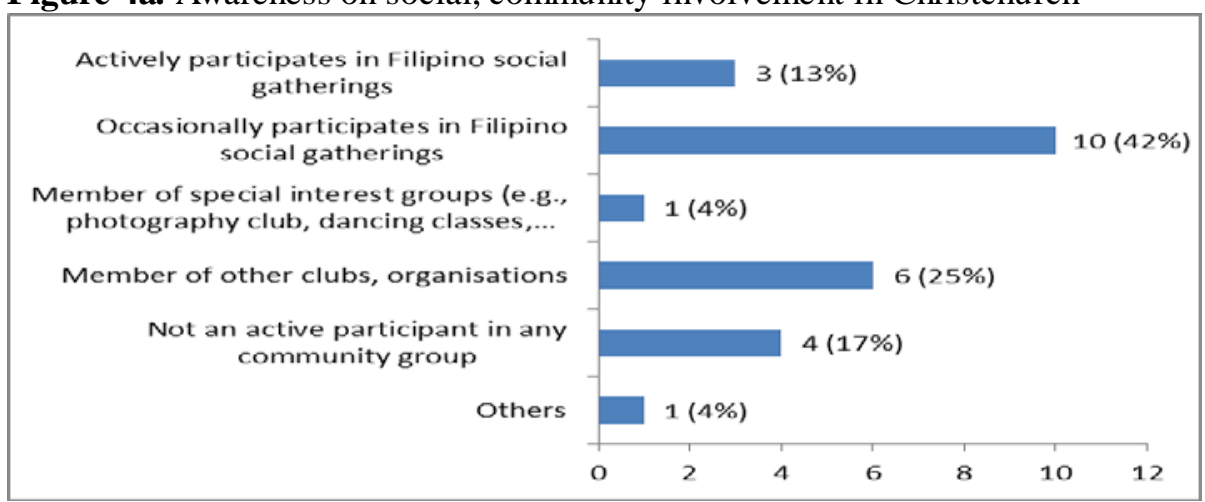

Source: Authors’ survey

Figure 4b. Awareness on social, community involvement in Tohoku/Kanto

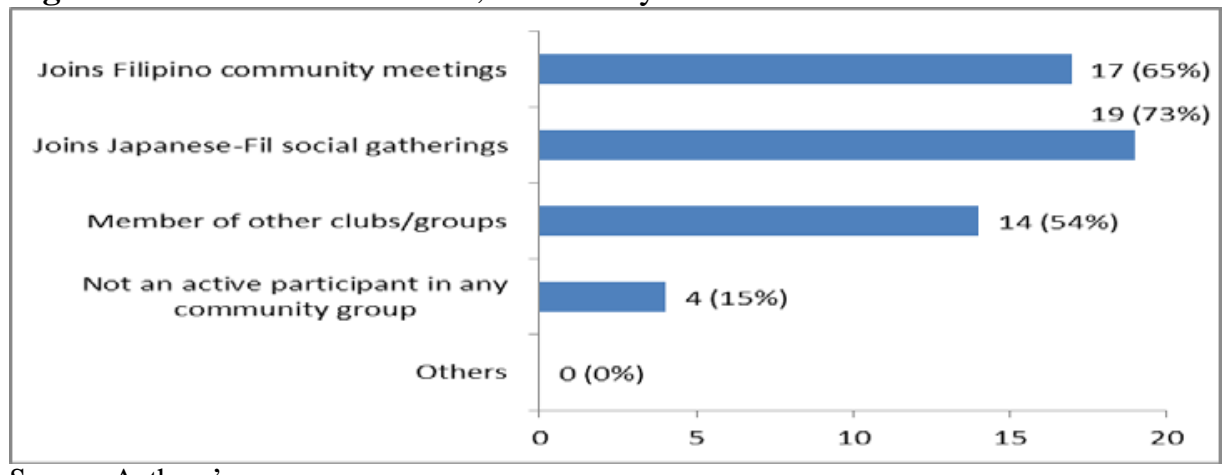

Source: Authors’ survey

Figure 5a. Language and communication skills of Tohoku/Kanto respondents

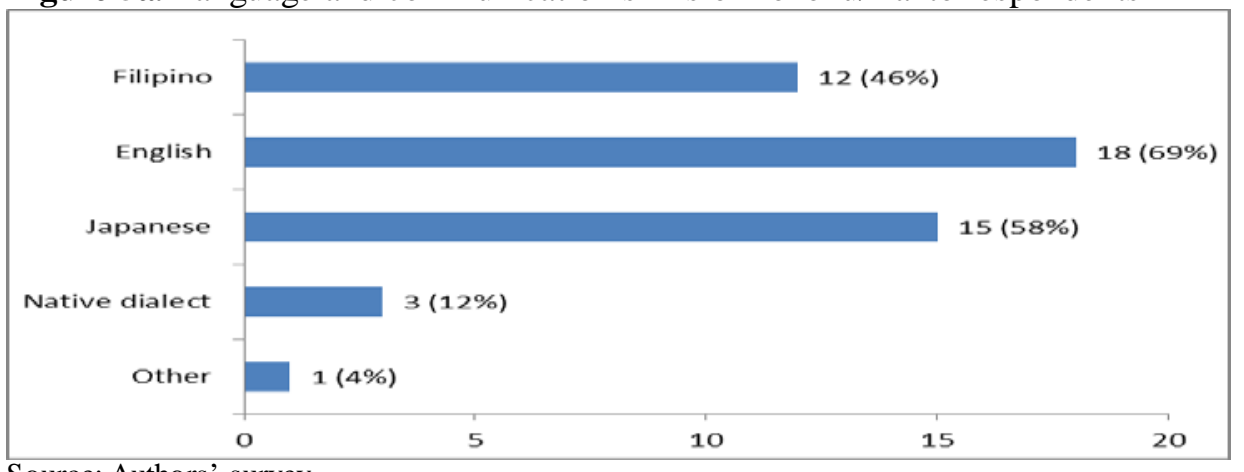

Source: Authors’ survey

Figure 5b. Japanese Language and communication skills proficiency for Tohoku/Kanto respondents

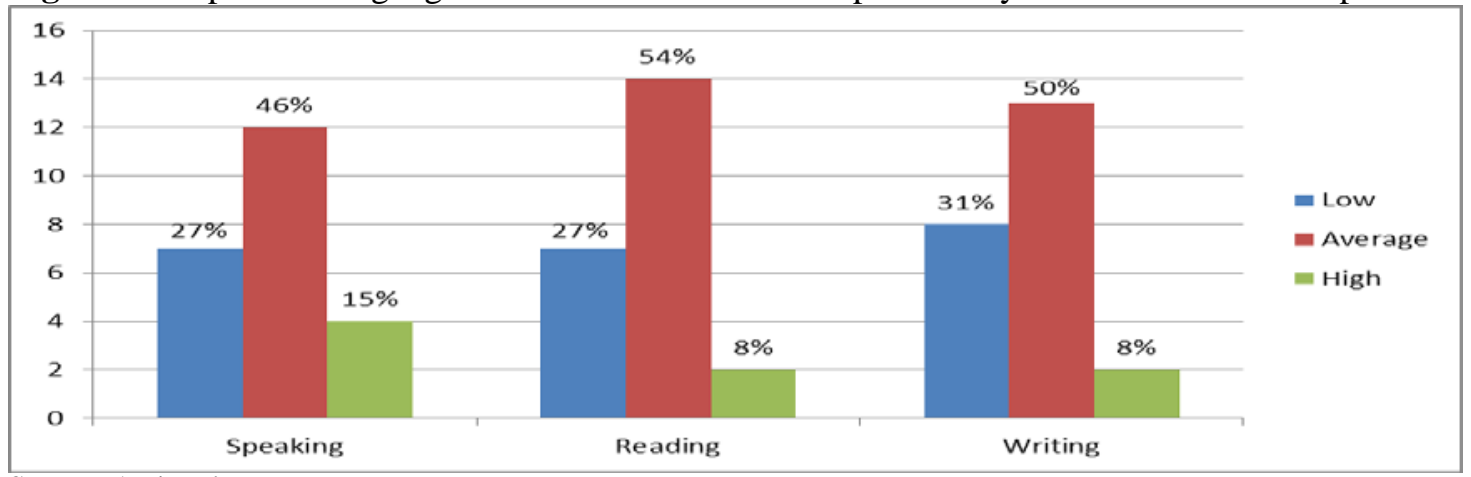

Source: Authors’ survey 
Japan Social Innovation Journal, Vol. 6, No. 1, 2016

Figure 5a shows the responses on language/s used for daily activities in which multiple answers are allowed. This question was added to the survey for the respondents in Japan due to the specific cultural setting that creates the need to learn the Japanese language as well as be familiar with the Hiragana, Katakana, Kanji characters, pronunciation and grammar for survival. As Figure 5a shows, more than half of the respondents use English, Japanese and Filipino in conducting their daily activities in Japan. These results indicate that the Filipinos use Japanese out of necessity to communicate with their family, neighbors, colleagues, teachers of their children, neighbors, and all the other people that they come in contact daily. During the interviews, some respondents even mentioned that they feel more "at home" in using the Kessenuma dialect more than standard Nihongo or hyojungo. Understandably, most of these old-timers have spent more than half of their lives in Japan and have enrooted themselves in their chosen "home-away-from-home" with their very own families and circle of friends.

Figure 5b supports another implication that can be drawn from Figure 5a. As some of the respondents assess their own Japanese language capability, a number of them do not know how to speak, read nor write Nihongo. Not knowing the Japanese language makes these Filipinos highly vulnerable particularly in emergency situations. In this case, English language capability save the day for Filipino migrants who revolve in largely multilingual circles of professionals or long-time associates. Thus, it is understandable that as shown in Figure 5a, English is the most frequently used language in this sample of Filipino respondents in the Kanto and Tohoku regions.

Moreover, it is interesting to note that as Figure 5a shows, they also actively use the native language of Filipino presumably implying that their networks of Filipino friends are actively utilized in their daily activities in Japan. For most of the respondents in this sample, Filipino is used as a secondary or backup tool for communication as it may be used interchangeably with English or their native dialects when confirming with other Filipinos who act as key persons in validating information received in Japanese. Among their support groups, Filipinos find themselves in various situations such as when they meet as a community or seek each other's advice personally or console each other when they face problems, or while traveling with buddies or while having a simple and relaxing tête-à-tête over coffee or tea.

These results imply that Filipino respondents have an acute awareness of the importance of having adequate social networks. Those who participated in social gatherings were not only able to gather information but also they were able to talk more freely about their earthquake experiences to family and friends. As shown in Figure $4 \mathrm{~b}, 65.4 \%$ of the respondents who experienced the earthquake actively participate in the Filipino community activities. A high degree of social and cultural competence is exhibited by these Filipino respondents who also sought membership in clubs and organisations in a way to be able to talk more openly with other people who are unlike themselves, and which could serve as a very effective way of reducing stress thus, allowing people to recover more quickly from the trauma of the earthquakes. 
Japan Social Innovation Journal, Vol. 6, No. 1, 2016

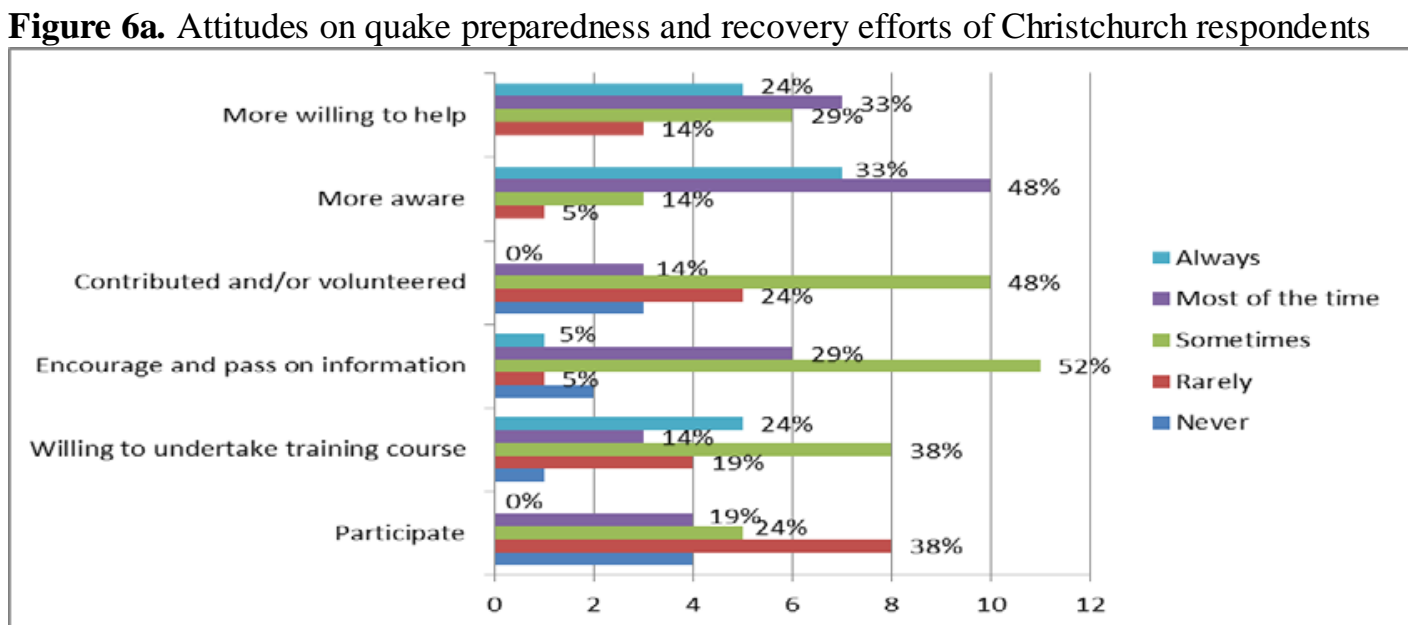

Source: Authors' survey

Notes: Full response statements are:

More willing to help: I am more willing to seek out individuals/households who may be in need following earthquakes. More aware: I am more aware of the vulnerability and needs of individuals during and after earthquakes.

Contributed and/or volunteered: I have contributed (money, food or clothing) to and/or volunteered in the earthquake recovery efforts.

Encourage and pass on information: I encourage and pass on information about preparedness and recovery efforts to other members of the community.

Willing to undertake training course: I am willing to undertake training course (e.g., how to perform CPR, use defibrillators, etc.) to be qualified to help during and after disasters.

Participate: I participate regularly in preparedness and recovery meetings.

Figure 6b. Knowledge on quake preparedness and recovery efforts in Tohoku/Kanto respondents

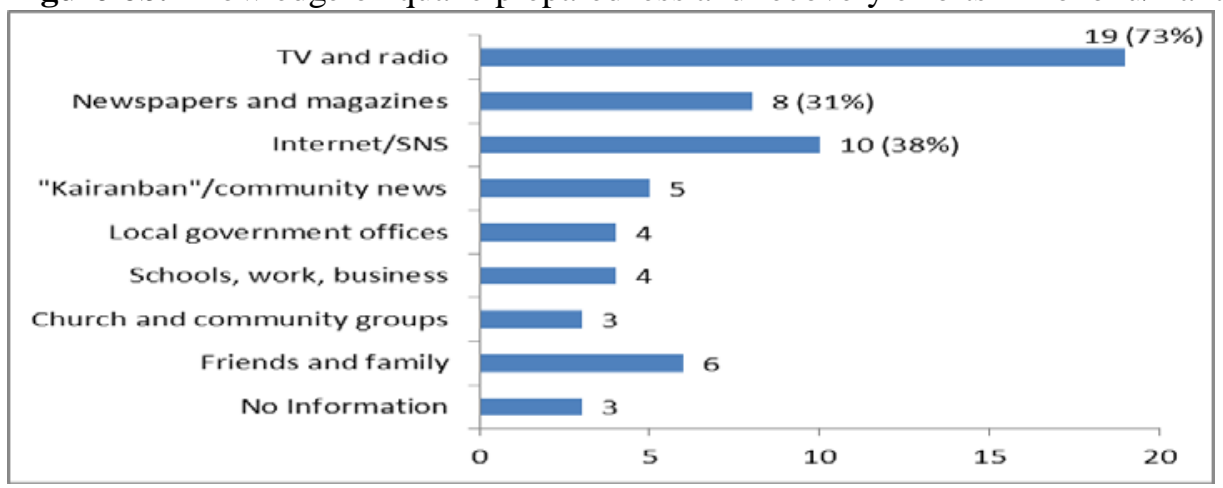

Source: Authors’ survey

The ability to connect and interact with both Japanese and Filipinos is a great asset for the Filipinos particularly those with no problem communicating in Japanese. The two factors of social networks and language communication skills are prerequisites to having a proactive attitude towards disaster preparedness. Language skills may not be as critical for Filipino migrants in New Zealand but in Japan, knowledge of the host country's (Japan's) language, lessens the risk and vulnerability of foreign residents considerably. As seen in Figures 6a-b, most of the Filipinos surveyed in in this study were able to cope with the disaster by actively seeking information about the different services offered by the local government offices or city council as well as other regional and national authorities. They relied on different forms of mass media (TV, newspapers, radio, internet) as well as social media for information as shown in Figures 6a-b.

Figure 6a shows that Filipino migrants in Christchurch are keeping themselves informed and aware about disaster preparedness community activities. However responses in Figure 6c, show a high incidence of non-participation in quake drills as well as in community voluntary activities for the Filipino respondents in the Kanto and Tohoku regions. Neither do they exhibit an interest in sharing 
Japan Social Innovation Journal, Vol. 6, No. 1, 2016

nor discussing information related to disasters. This is highly understandable for those who do not understand the Japanese language - as they are not capable of accessing this vital information. However, it is possible that aside from the Japanese language deficiency of some Filipinos, other Filipinos, most of whom live in Metropolitan Tokyo who do know the language are too busy with work or family to go out of their way to join disaster preparedness activities in the community and emergency drills.

The seemingly indifferent attitude towards disaster prevention among Tokyoites runs in stark contrast against the keyed in responses that they are "more aware of the disaster risks after 3/11 disaster." And a high incidence of sharing or donating resources "many times" for relief and recovery process is also one of the main results shown in Figure 6c. This implies that the Filipinos are capable of exhibiting empathy towards the less fortunate and doing what they can to help others. So if they are capable of helping others, why do we get these seemingly contradictory results?

Figure 6c. Attitudes on quake preparedness and recovery efforts of Tohoku/Kanto respondents

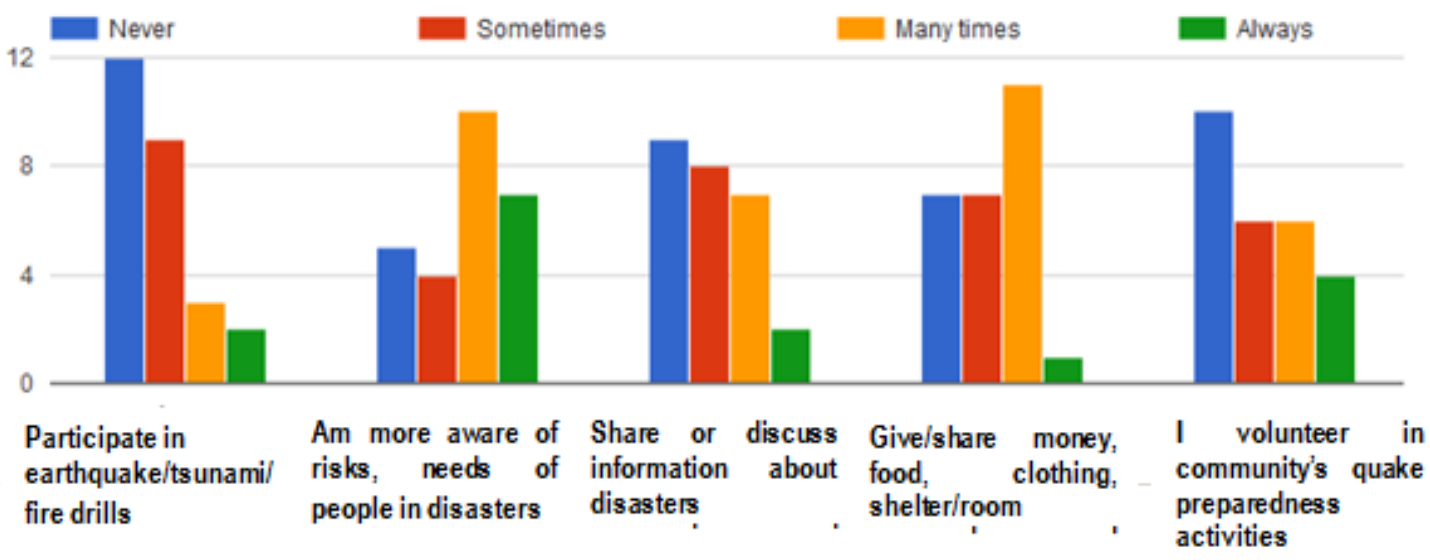

Source: Authors’ survey

Follow-up questions via SNS and text messages were sent to clarify this matter. We found out that they simply did not know when or where emergency drills were being conducted. Information in languages other than Japanese about charity drives in their places of work, in school, at church, online, etc. are more ubiquitous than notices about emergency drills (disseminated mostly in Japanese as of the end of 2015).

In Figure 6c, we see the need for a two-way process in nurturing a healthy proactive attitude towards disaster preparedness in a community. We argue that this is where the host society (in this case, Japan) can have considerable influence. The host society needs to recognize that disaster management has to take into account the presence of foreign nationals who may or may not have language setbacks. A disaster management program that includes or integrates migrants in the framework would improve information dissemination that will in turn foster "a sense of belonging" of these migrants in their communities. In comparison, the results from Christchurch imply that New Zealand seems to be doing fairly well in keeping the communities like those of the Filipinos informed or at least motivating them to actively seek information about how they can keep themselves and their communities less vulnerable or more secure during crisis episodes.

\section{DISCUSSION: Social competence, “bayanihan" community spirit and resilience}

We argue in this paper that residents who strongly feel that they have a stake in the region or cities are more resilient than residents who do not feel as strongly towards the region or city. Migrants who chose to stay rather than return to their homeland or move to safer ground is a strong indication that 
those foreign residents feel they have a stake in the community or that they have a role to play in the post-disaster relief and recovery phases.

Migrants are said to often bring with them traditions and customs from their homeland. Bauzon (2006) describes the sense of community and Filipino tradition of mutual cooperation or "bayanihan" in Tagalog as the basis of the social support systems of the Filipino. It is based on a sense of belonging, identification and security shared with members of the community.

Below are some examples of how Filipinos in both Christchurch and Tohoku are contributing to the post-disaster relief and recovery in their communities through self-help and mutual cooperation. Note that some of the organizations mentioned below were established before the earthquakes and others, established primarily as a response to the earthquakes. These particular examples were chosen to provide us a glimpse of the importance of being part of social networks pre- and post-disasters, as well as the Filipinos' awareness of the need to be more cooperative and responsive when specific needs arise (e.g., when disasters strike).

1. Mga Pinoy ng Christchurch is an online social networking site on Facebook established in October 2010, prior to the February 22, 2011 earthquake. This Facebook group serves mainly to inform members of various social activities that Filipinos living in the area may be interested in. After the earthquakes, the group's web page also regularly posts information on recovery efforts initiated by Filipino groups or local and regional government organizations like the Christchurch City or the Canterbury Regional Councils.

2. Canterbury Philippines Assistance Group (CPAG) was established after the February 22, 2011 earthquake to provide assistance and relief to the members and families of Filipino victims

3. Bayanihan Kesennuma Filipino Community is a group of 76 members ${ }^{5}$ who joined forces in May 2011 to help each other after the March 11 earthquake and tsunami washed away their homes, took away their jobs, and claimed the lives of their loved ones. It has received recognition from the Japanese and Philippine local governments, media and NPOs for the activities of its various members practicing "Bayanihan" (mutual cooperation) spirit to help in the recovery of Kessenuma and energize their local communities. The Bayanihan Kessenuma Filipino community has garnered awards and recognition in the Philippines like the Global Bayaning Pilipino Award in 2014 for the group's numerous social contribution projects such as the Bayanihan Kessenuma Radio project (in cooperation with FMYY, a popular multi-language station in Kobe) where they produced and aired a radio program disseminating information on disaster-related issues from their own living room.

4. Kessenuma foreign caregivers: This project involves the Bayanihan Kessenuma Filipino community members who were trained as caregivers' right after the earthquake. The Kessenuma city office and some non-profit organizations collaborated to create new job opportunities for the foreigners who have stayed on in Kesennuma. The Japan Association for Refugees was the NPO that started offering intensive language-training classes to the Filipino women in April 2011. The city office then started seminars in cooperation with support groups to help them obtain entry-level licenses to work at elderly nursing homes, which were short-staffed (Kamiya, 2012, Hirano, 2014).

5. Social Enterprise English Language School (SEELS): This social enterprise was established in 2012 by Mr. Cesar Santoyo, a Filipino living in Fukushima. SEELS provides training to Filipinos to become certified English teachers. Through these well-trained teachers, SEELS delivers English language teaching services mainly targeting middle- and low-income families in various parts of the Tohoku region. The SEELS business model aims to harness the Filipino migrants as local resources in the creation of jobs and disaster recovery through employment

\footnotetext{
${ }^{5}$ As of March 2015.
} 
Japan Social Innovation Journal, Vol. 6, No. 1, 2016

generation and provision of learning opportunities in the local communities. SEELS has won two awards to date under the leadership of Mr. Santoyo. This includes the Philippine's Global Bayaning Pinoy Award in 2012 and a grant from Japan's 1st Michinoku Entrepreneurship program funded by the Social Incubator Fund launched by the Cabinet Office and non-profit organization called the Entrepreneurial Training for Innovative Communities (ETIC). Mr. Santoyo is also the Executive Director of the Center for Japanese Filipino Families (CJFF) (Akira Foundation, 2012).

\section{CONCLUSION}

This study offers two contributions to the literature. First, we consider the human security implications of natural disasters at the micro or individual level. In particular, we explain how socially and culturally competent migrants are able to overcome vulnerability in disaster episodes. The analysis draws from the results of a survey of two groups of Filipino migrants who experienced the Christchurch and the Great East Japan earthquakes in 2011 and yet decided to stay to help each other as a community and to contribute in their town's post-disaster relief and recovery efforts.

The results of the surveys imply the importance of (1) awareness, (2) attitudes, (3) knowledge, (4) language communication skills in attaining social competence. Having ample support from social networks during the earthquakes and language communication skills enhance gathering valid information during disasters. The survey results imply that those who participated in social gatherings were able to gather information and at the same time talk more freely about their earthquake experiences to family and friends. On the other hand, those who are members of other clubs and organizations can talk more openly with other people, which could be a very effective way of reducing stress and allowing people to recover more quickly from the trauma of the earthquakes.

Second, by giving concrete examples of project initiatives of a group of Filipino migrants in New Zealand and Japan, we further link the concept of social competence of migrants who in their quest for a sense of belonging, find ways to give back by helping each other and supporting recovery initiatives in their devastated communities. Although a growing number of studies focus on the benefits of social networks and resilience, to our knowledge, there are no studies to date that have empirically examined the dynamic interaction of vulnerability, social competence and resilience of migrants through the prism of human security.

Our results suggest that vulnerability and resilience are two sides of the same coin called human security. The individual characteristics that determine resilience are the same characteristics when lacking make individuals vulnerable to the risks and uncertainty presented by disastrous situations. Furthermore, we argue that even for migrants with ample social networks and language abilities, the role of the host society in recognizing the presence and integrating foreign nationals in disaster management planning is critical for the initial point of information access and provision of security and assurance to all residents and members of the community regardless of nationality or ethnicity.

\section{ACKNOWLEDGEMENTS}

We acknowledge the support of the Hyogo Earthquake Memorial 21st Century Research Institute for inviting Dr. Arlene Garces-Ozanne to visit the University of Hyogo in November-December 2015 under the Hyogo Overseas Research Network (HORN) Research Fellowship grant. We are also grateful for the valuable cooperation of the officers and members of the Bayanihan Kessenuma community who participated in the interviews and online survey. We also wish to thank the publisher and editor of Jeepney Press (a news magazine for Filipinos based in Japan) who helped us contact Filipinos in the Tohoku and Kanto regions. 
Institute for Policy Analysis and Social Innovation, University of Hyogo

Published online: March 31, 2016

Japan Social Innovation Journal, Vol. 6, No. 1, 2016

\section{REFERENCES}

Adams, AM, Cekan, J and Sauerborn, R. (1998). Towards a conceptual framework of household coping: Reflections from rural West Africa, Africa, 68(2), 263-283.

Adger, WN. (1999). Social vulnerability to climate change and extremes in coastal Vietnam, World Development, 27, 249-269.

Akira Foundation. (2012). Projects: Social Enterprise English Language School (SEELS). Retrieved from http://www.akira-foundation.org/whatwedo/projects/p_seels. [Accessed 2015-12-4].

Aota, Ryosuke. (2012). Consideration of "New Public Commons" Characteristics for Disaster Reconstruction, Japan Social Innovation Journal, Vol. 2 , No. 1 , 2012.

Bartashius, Jason. (2015). “Filipinos in Japan call for acceptance with new film”. The Japan Times. January 12, 2015. Retrieved from http://www.japantimes.co.jp/community/2015/01/12/issues/filipinos-japan-issue-call-acceptancefilm-challenging-stereotypes/\#.VqJ6GVKPZCF. [Accessed 2015-12-4].

Bauzon, Leslie E. (2006). “Migration and Geographical Distance.” In Kleinschmidt, Harald (2006). Migration, Regional Integration And Human Security: The Formation And Maintenance of Transnational Spaces, pp. 123-138.

Brooks, N, Adger, WN and Kelly, PM. (2005). The determinants of vulnerability and adaptive capacity at the national level and the implications for adaptation, Global Environmental Change, 15, 151-163.

Canterbury Philippines Assistance Group homepage. http://kacpag.org.nz/. [Accessed 2015-11-17].

Cordina, G. (2004). Economic vulnerability and economic growth: Some results from a neo-classical growth modelling approach, Journal of Economic Development, 29(2) December, 21-39.

Cutter, SL and Finch, C. (2007). Temporal and spatial changes in social vulnerability to natural hazards, Proceeding of the National Academy of Sciences if the United States of America, 105(7), 2301-2306.

de Ville de Goyet C, Marti RZ, Osorio C. Natural Disaster Mitigation and Relief. In: Jamison DT, Breman JG, Measham AR, et al., editors. Disease Control Priorities in Developing Countries. 2nd edition. Washington (DC): World Bank; 2006. Chapter 61. Retrieved from http://www.ncbi.nlm.nih.gov/books/NBK11792/. [Accessed 2015-11-30].

Duncan, Howard. (2013). "Immigration integration as a factor in disaster preparedness: The case of the 2011 Tohoku earthquake in Japan.” Migration Policy Practice, Vol. III, Number 2, April 2013-May 2013, pp. 9-15.

Flanagan, Barry E., Gregory, Edward W., Hallisey, Elaine J., Heitgerd, Janet L., and Lewis, Brian. (2011). "A Social Vulnerability Index for Disaster Management," Journal of Homeland Security and Emergency Management: Vol. 8: 1, Article 3, pp. 1-22. Retrieved from http://gis.cdc.gov/grasp/svi/A\%20Social\%20Vulnerability\%20Index\%20for\%20Disaster\%20Ma nagement.pdf . [Accessed 2015-6-10].

Futamura, M, Hobson, C and Turner, N. (2011). Natural Disasters and Human Security, United Nations University article, 2011-04-29, Retrieved from http://unu.edu/publications/articles/natural-disasters-and-human-security.html. [Accessed 2015-11-30]. 
Government of Japan. “Highlighting Japan”, March 2012. Retrieved from http://dwl.gov-online.go.jp/video/cao/dl/public_html/gov/pdf/hlj/20120301/16.pdf. [Accessed 2015-3-9].

Global Peace Foundation. (2013). "Filipino Community Energizing Disaster Affected City Kesennuma in Japan.” Retrieved from http://gpf.jp/2176/. [Accessed 2015-3-9].

Guha-Sapir, D, Below, R, Hoyois, and Ph. EM-DAT: International Disaster Database. http://www.emdat.be . Université Catholique de Louvain, Brussels, Belgium. [Accessed 2015-11-30].

Guillaumont, P. (2009). An economic vulnerability index: Its design and use for international development policy, Oxford Development Studies, 37(3) September, 193-228.

Hirano, Yugo. (2014). “Elderly perked up by caregiver.” The Japan Times, February 25, 2014. Retrieved from http://www.japantimes.co.jp/news/2014/02/25/national/elderly-perked-up-by-filipino-caregiver/\#. Vq8dpeaPZCF. [Accessed 2015-6-10].

Hyogo Earthquake Memorial 21st Century Research Institute. (2014). 「生活復興のための 15 章. 〜「東日本大震災生活復興プロジェクト」報告〜」 (Seikatsu Fukkou no tame no Juugo sho "Higashi Nihon Daishinsai Seikatsu Fukkou Projekto" Houkoku一).

Ikeda, Maria M., and Matsumaru, Miharu. (2012). Leadership and Social Innovation initiatives at the Grassroots during Crises, Japan Social Innovation Journal, Vol.2, No.1, p. 79, 2012.

Kamiya, Setsuko. (2011). “Kessenuma Filipinos closer knit than ever.” The Japan Times. June 6, 2011. Retrieved from http://www.japantimes.co.jp/news/2011/06/11/national/kesennuma-filipinos-closer-knit-than-ever /. [Accessed 2015-6-10].

Kleinschmidt, Harald. (2006). Migration, Regional Integration And Human Security: The Formation And Maintenance of Transnational Spaces. Hampshire: Ashgate.

Ministry of Health, Labour and Welfare of Japan. (2012). Statistics of Casualties/Death caused by the Great East Japan Earthquake (Jinkō dōtai tōkei kara mita Higashinihon daishinsai ni yoru shibō no jōkyō ni tsuite) (As of September 2012). Retrieved from http://www.mhlw.go.jp/toukei/saikin/hw/jinkou/kakutei11/dl/14_x34.pdf. [Accessed 2016-1-27].

Ministry of Justice of Japan. Retrieved from http://www.moj.go.jp/housei/toukei/toukei_ichiran_touroku.html. [Accessed 2016-1-27].

Mishina, S. (2015). "Natural disaster Four years on, world watches Tohoku's reconstruction”, Nikkei Asian Review, March 9, 2015. Retrieved from http://asia.nikkei.com/Politics-Economy/International-Relations/Four-years-on-world-watches-To hoku-s-reconstruction. [Accessed 2015-6-10].

National Police Agency of Japan. Heisei 23 Nen (2011) Tōhoku chihō Taiheiyō oki jishin no higai jōkyō to keisatsu sochi (2011 Tohoku Northeast Pacific Ocean Earthquake damage situation and police measures). (As of January 8, 2016). Retrieved from http://www.npa.go.jp/archive/keibi/biki/higaijokyo.pdf. [Accessed 2016-1-22].

Naude, W, McGillivray, M and Rossouw, S. (2009). Measuring the vulnerability of subnational 
Japan Social Innovation Journal, Vol. 6, No. 1, 2016

regions in South Africa, Oxford Development Studies, 37(3) September, 249-276.

New Zealand Police website. List of Deceased. Figures as of February 9, 2012. Retrieved from http://www.police.govt.nz/major-events/previous-major-events/christchurch-earthquake/list-dece ased. [Accessed 2016-1-27].

Parker, M. and Steenkamp, D. (2012). The economic impact of the Canterbury earthquakes, Reserve Bank of New Zealand: Bulletin, vol.75, no. 3, September 2012.

Perrow, Charles, The Next Catastrophe (Princeton, NJ: Princeton University Press, 2007.

Rayhan, MI. (2008), Assessing household vulnerability and coping strategies to floods: A comparative study of flooded and non-flooded areas in Bangladesh, 2005. Cuvilliar Verlag, Goettingen.

Statistics Bureau, Ministry of Internal Affairs and Communications of Japan. Retrieved from http://www.e-stat.go.jp/SG1/estat/List.do?lid=000001133760. [Accessed 2015-6-27].

United Nations Sustainable development blog. (2016). "244 million international migrants living abroad worldwide, new UN statistics reveal.” Retrieved from http://www.un.org/sustainabledevelopment/blog/2016/01/244-million-international-migrants-livi ng-abroad-worldwide-new-un-statistics-reveal/. [Accessed 2016-1-27].

(cc) EY-NC

Open Access Article. This work is licensed under a Creative Commons Attribution-NonCommercial 3.0 Unported License. To view a copy of this license, visit http://creativecommons.org/licenses/by-nc/3.0/.

\section{Publisher:}

Institute for Policy Analysis and Social Innovation, University of Hyogo 